The Polish Journal of the Arts and Culture. New Series 13

(1/2021): 133-152 [ARTYKUE]

DOI: $10.4467 / 24506249$ PJ.21.007.13734

\title{
Obcokrajowcy w kulturze flamenco: problem negocjacji tożsamości
}

\author{
Jadwiga RomanowskA
}

\begin{abstract}
Streszczenie
Artykuł traktuje o cudzoziemcach pragnących zostać profesjonalnymi tancerzami flamenco w Sewilli i o związanych z tym pragnieniem wyzwaniach tożsamościowych, przed jakimi stają. Obcokrajowcy stanowią zasadniczą większość w sewilskich szkołach tańca i to dzięki nim szkoły te mogą istnieć. Decydując się na dłuższy pobyt w Sewilli, wkraczają oni w transkulturowe pole wymiany, przez co zostają wpisani w relacje władzy - podporządkowania i dominacji. Ich sytuację oraz relacje zachodzące $\mathrm{w}$ sewilskiej przestrzeni bardzo dobrze opisują kategorie transkulturacji/transkulturowości oraz tożsamości transkulturowej. Cudzoziemcy pragnący zaistnieć w profesjonalnym świecie flamenco w Sewilli czy szerzej w Hiszpanii konstruują swoją tożsamość, negocjując poszczególne jej elementy. W tekście omówione zostały trzy z nich: ekspresja, ruch i ciało. Są czynnikami autodefiniującymi oraz elementami decydującymi o wykluczeniu i/lub „dyskryminacji” ze strony autochtonów i zagranicznych widzów.
\end{abstract}

SŁOWA KLUCZE: taniec, flamenco, tożsamość, transkulturacja

JADWIGA RomanowsKa - kulturoznawczyni, komparatystka kultury, doktor nauk humanistycznych w zakresie kulturoznawstwa, dyplomowana instruktorka tańca. Jej zainteresowania badawcze skupiają się wokół pojęcia transkulturowości oraz tożsamości transkulturowej, studiów postkolonialnych, a także szeroko rozumianej antropologii tańca.

(iD https://orcid.org/0000-0002-7588-2373

E-MAIL: jadwiga.romanowska@alumni.uj.edu.pl 
W listopadzie 2010 roku flamenco zostało wpisane na Listę niematerialnego dziedzictwa ludzkości UNESCO ze względu na jego uniwersalny charakter. W siódmą rocznicę tego wydarzenia Rafael Estévez, dyrektor artystyczny Andaluzyjskiego Baletu Flamenco (hiszp. Ballet Flamenco de Andalucía), opublikował manifest, w którym możemy przeczytać:

Flamenco to podstawowy znak rozpoznawczy tożsamości andaluzyjskiej i dzięki jego uniwersalności osoby pochodzące z innych kultur identyfikują się z nim i mogą je czuć jako coś własnego, gdyż flamenco należy do ludzkości... Od Nowego Jorku po Grenadę, od Sewilli po Japonię, od Jerez po Chiny bądź Tajwan, od Grecji po Madryt, od Finlandii po Barcelonę, od Malagi po Rosję, od Kadyksu po Amerykę Łacińską, od La Unión po Francję, od Kordoby po Kanadę, od Huelvy po Australię flamenco się czuje, kocha, szanuje i żyje nim, bo [...] „flamenco to kawał ludzkiego serca”.

Te słowa, ujęte w nieco mniej poetycką formę, mogłyby służyć opisowi zróżnicowania kulturowego społeczności, której dotyczy niniejszy tekst. Niemal wszystkie wspomniane przez Esteveza pozahiszpańskie lokalizacje są miejscami pochodzenia zagranicznych tancerzy flamenco, z którymi miałam okazję rozmawiać podczas jego przygotowywania. Artykuł traktuje o obcokrajowcach, którzy deklarują, że flamenco czują, kochają, żyją nim oraz pragną być częścią społeczności flamenco w Sewilli².

Ich sytuację oraz relacje zachodzące w sewilskiej przestrzeni bardzo dobrze opisują kategorie transkulturacji/transkulturowości oraz tożsamości transkulturowej. Ukuty na przełomie lat trzydziestych i czterdziestych

1 Za: https://www.facebook.com/rafaelestevezoficial/photos/a.668204663265382.1073741828. 668176266601555/1522207781198395/?type=3\&theater. Dostęp: 17.11.2017.

2 Podczas wykonywanych między 2013 a 2016 rokiem badań terenowych przeprowadzono 61 wywiadów pogłębionych: 43 z obcokrajowcami tańczącymi flamenco, 10 z uczniami Hiszpanami oraz 8 (2 podwójne) z nauczycielami szkół tańca. Najważniejszym materiałem badawczym były dla mnie w tym kontekście wywiady z obcokrajowcami. Pozostałych 18 potraktowałam pomocniczo i porównawczo. Warto podkreślić, że obserwacja uczestnicząca była dla mnie niemal równie ważną metodą. Połączenie obserwacji i wywiadów pozwoliło mi na „wejście” głębiej w środowisko zagranicznych tancerzy flamenco w Sewilli. Dzięki temu spędzałam z tą grupą dużo więcej czasu, co zaowocowało nieoficjalnymi rozmowami, podczas których moje rozmówczynie i rozmówcy poruszali kwestie, o których nie chcieli mówić przy włączonym mikrofonie. Mimo moich zapewnień o anonimowości wywiadów bali się, że ich słowa obrócą się przeciwko nim. Byli oczywiście też tacy, którzy wręcz nie chcieli pozostać anonimowi, przy kwestiach najdelikatniejszych (związanych z ewentualną dyskryminacją) większość badanych jednak wręcz bała się włączonego mikrofonu. Ich zaufanie zdobywałam bardzo powoli, wciąż mediując na granicy perspektywy etic i emic. 
XX wieku przez kubańskiego historyka i antropologa Fernanda Ortiza termin transkulturacja (Ortiz 2002) posiada bardzo duży potencjał eksplanacyjny. Dla Ortiza służył do opisania procesu wymiany kulturowej, zachodzącej w relacji władzy i podporządkowania między ludnością rdzenną a kolonizatorami na Kubie. W jego opinii transkulturacja „najlepiej wyraża różne fazy przejścia z jednej kultury do drugiej, ponieważ nie polega tylko na zdobywaniu innej kultury, ale implikuje konieczność utraty czy też wykorzenienia wcześniejszej kultury [...] i co więcej, oznacza wynikającą z tego kreację nowych fenomenów kulturowych" (Ortiz 2002, 144). Nowo powstały twór jest zawsze obdarzony cechami wszystkich kultur, które uczestniczą $\mathrm{w}$ procesie wymiany kulturowej. W tym kontekście transkulturacja ma charakter dynamiczny, złożony, kreatywny, sytuacyjny i heterogeniczny. Może zachodzić na różnych poziomach i etapach kontaktu kulturowego (Kubiaczyk, 2013, 254).

Na gruncie europejskim pojęcie transkulturowości jest przede wszystkim kojarzone z niemieckim filozofem i historykiem sztuki Wolfgangiem Welschem, który stworzy własną koncepcję transkulturowości i tożsamości transkulturowej (Welsch 1998, 195-221). Wychodząc od krytyki herderowskiej wizji kultury jako całości oraz uznając istniejące koncepcje wielokulturowości oraz interkulturowości za nieadekwatne do opisu współczesnej rzeczywistości, Welsch proponuje, by kulturę rozumieć w kategoriach kulturowych sieci (Welsch 1999). W świecie globalnych przepływów „dla każdej kultury, wszystkie inne kultury stopniowo stały się wewnętrznymi treściami, albo ich satelitami” (Welsch 1998, 205). Niemiecki filozof analizuje zjawisko transkulturowości na dwóch poziomach: makro i mikro. Poziom makro dotyczy całych społeczeństw. Natomiast mikro „sięga też mikropoziomu tożsamości indywidualnej” (Welsch 2004, 34). W tym kontekście Welsch pisze o tożsamości transkulturowej. Według badacza ludzie o takiej tożsamości cechują się dużą otwartością na innych. Łączą w sobie aspekt kosmopolityczny i lokalną afiliację. Dzięki temu są chętni do międzykulturowego dialogu bardziej niż jednostki monokulturowe (Welsch 2004, 35). Należy zauważyć, że koncepcja transkulturowości i tożsamości transkulturowej jest zdaniem jej autora diagnozą społeczeństwa i tożsamości w fazie przejścia, trudno przewidzieć, co będzie jej kontynuacją. Mimo że omawiane wcześniej koncepcje powstały w różnych kontekstach historycznych i kulturowych, doskonale się dopełniają. Warto podkreślić, że termin transkulturacja przyjął się także w kręgu hiszpańskojęzycznych naukowców zajmujących się problematyką flamenco (Lorente Rivas 2004, 2005; Steingress 2005, 2007). W kontekście ni- 
niejszego artykułu tożsamość transkulturową rozumiem jako proces ciągłej negocjacji znaczeń, wartości, stylu życia, zachodzący w podwójnej relacji ja - mnie (w kontekście tożsamości własnej) i ja - inny (w odniesieniu do autochtonów zajmujących się flamenco). Cudzoziemcy pragnący zaistnieć w profesjonalnym świecie flamenco w Sewilli czy szerzej w Hiszpanii konstruują swoją tożsamość, negocjując poszczególne jej elementy. Wśród nich można wymienić: styl życia/sposób zachowania, język, ekspresję, ruch i ciało. W tekście skupię się na trzech ostatnich składnikach tożsamości zagranicznych tancerzy ${ }^{3}$.

Jakkolwiek niniejszy tekst traktuje o tańcu, należy zauważyć, że flamenco to kultura, która narodziła się na południu Hiszpanii, w Andaluzji, a jej podstawowymi manifestacjami są muzyka (śpiew i gra na gitarze) oraz taniec. Jako w pełni ukształtowany gatunek wyłoniło się w drugiej połowie XIX wieku w środowisku bohemy andaluzyjskiej (Steingress 2007, 16). Zawiera w sobie spuściznę większości tradycji muzycznych i tanecznych, które były obecne na przestrzeni wieków w Andaluzji. Jak zauważa badaczka flamenco Emilia Dowgiało $(2018,21)$, flamenco nie jest folklorem, ponieważ zawsze było wykonywane przez artystów profesjonalnych, jednak niektóre jego formy uległy popularyzacji. Flamenco, jakie znamy dziś, przybrało znaną nam formę dzięki artystom stanowiącym elitę andaluzyjskiej bohemy: „Za ich sprawą nastąpiła fuzja andaluzyjskiego folkloru - chrześcijańskiego, cygańskiego, muzułmańskiego i żydowskiego, ubranych w nową formułę romantycznej ekspresji" (Dowgiało 2018, 21). W środowisku flamenco uważa się jednak, że flamenco to coś więcej niż artystyczny przekaz; w tym kontekście często mówi się, że jest ono stylem czy filozofią życia. Należy tu wspomnieć, że analizując kulturę flamenco, rozróżnia się flamenco de cambio - wykonywane publicznie dla zysku, oraz flamenco de uso - zarezerwowane dla prywatnej sfery życia społeczności flamenco (Cruces-Roldán 2002, 57-58). Sfery te często przenikają się i niejednokrotnie nie sposób ich od siebie oddzielić. Już na wstępie trzeba również zauważyć, że flamenco zostało sformułowane na do tej pory oddziałującym micie założycielskim (hiszp. la leyenda flamenca). Według niego flamenco powstało w społeczności andaluzyjskich Cyganów ${ }^{4}$

3 Ze względu na objętość tekstu koncentruję się w nim tylko na wybranych zagadnieniach związanych z tożsamością zagranicznych tancerzy. Czytelników zainteresowanych tą tematyką zapraszam do przeczytania mojego tekstu Kształtowanie się relacji widz - artysta we flamenco na przykładzie praktyki fin de fiesta, w: „Magazyn Antropologiczno-Społeczno-Kulturowy «Maska»", nr 43 (3/2019), s. 33-44.

4 Jakkolwiek w obecnym około romskim dyskursie odchodzi się od używania terminu „Cygan” ze względu na jego negatywne konotacje, w całym tekście posługuję się wymiennie terminami: 
jako forma ekspresji tej prześladowanej w Hiszpanii na przestrzeni wieków grupy. Ów mit jest zakorzeniony zarówno w świadomości pasjonatów, jak i niektórych naukowców (Schreiner 1999, 22), co prowadzi do licznych, wręcz zasadniczych błędów w postrzeganiu flamenco. Stąd bierze się przekonanie, że „prawdziwe”, „czyste” flamenco (tak zwane flamenco puro) to flamenco cygańskie (Steingress 2007, 33-37). Flamenco to jednak twór dużo bardziej złożony, niż chcieliby tego zwolennicy teorii romskiej proweniencji tej sztuki. To, co miałoby być ich zdaniem autentycznym flamenco, zostało zbudowane na przekłamanej opozycji: cygańskość versus andaluzyjskość. Flamenco puro nabrało w związku z tym ekskluzywnego charakteru. Budującą się w ten sposób silną antynomię wewnątrz flamenco (to, co, cygańskie, puro, autentyczne versus to, co andaluzyjskie, obce, nowe) dobrze obrazują dwa rodzaje podejść do flamenco. Pierwsze to stanowisko partykularystyczne (Iglesias Jiménez 2019, 24-28). Definiuje ono flamenco jako manifestację kulturową pewnej grupy (w zależności od podejścia cygańskiej, andaluzyjskiej bądź hiszpańskiej) - cechować ma ją określony styl życia, folklor, język, mentalność. Drugie podejście to podejście uniwersalistyczne i w tym rozumieniu flamenco pojmowane jest przede wszystkim jako forma artystycznego wyrazu. Z tej racji jako uniwersalna manifestacja kulturowa dostępne jest dla każdego, kto wyrazi chęć jego zgłębienia. Flamenco ma zatem być wyrazem tego, co uniwersalne, w tym, co lokalne. Taki sposób ujmowania flamenco zakłada jego otwartość na inne wpływy i wpisuje się w decyzję komitetu UNESCO. Jak widać, zjawisko to cechuje wiele sprzeczności. Tradycjonalizm społeczeństwa andaluzyjskiego i jego wpływ na kulturę flamenco ${ }^{5}$, liczne antynomie wewnątrz tej kultury, a także to, jak się ją postrzega z zewnątrz, powodują, że niełatwo jest zdefiniować całe pole semantyczne tego pojęcia.

„Rom” i „Cygan”. Używam pojęcia „Cygan” ze względu na jego powszechne użycie w hiszpańskojęzycznej literaturze naukowej dotyczącej flamenco oraz w świecie flamenco (hiszp. gitano). W tym kontekście nie jest ono tak negatywnie nacechowane jak w języku polskim.

5 Problem tradycjonalizmu społeczeństwa andaluzyjskiego w kontekście flamenco dobrze obrazują przykłady artystów hiszpańskiego pochodzenia, którzy mimo swojego niekwestionowanego talentu i doskonałej znajomości tradycyjnego flamenco zostali poddani swoistemu ostracyzmowi ze względu na nowatorskie podejście do tej sztuki. Wymienić tu można dwie mocno wybijające się postaci: pochodzącego z niezwykle uznanej rodziny flamenco tancerza Israela Galvana i święcącą tryumfy na światowych scenach katalońską piosenkarkę/śpiewaczkę Rosalię. Galván niejednokrotnie wzburzył publiczność przerysowanym, prześmiewczym tańcem, mocno odbiegającym od decorum flamenco. Rosalía natomiast, która sama definiuje się jako artystka w ogóle, nie zaś śpiewaczka flamenco, sprowadziła na siebie lawinę krytyki, wzbogacając swój repertuar o muzykę pop, reggaeton czy rap. 
Omawiane zagadnienia mają również realny wpływ na status obcokrajowców we flamenco oraz ich samopostrzeganie.

Warto zauważyć, że od początku istnienia flamenco cudzoziemcy konstruują jego historię. To dziewiętnastowieczni, romantyczni podróżnicy zafascynowani kulturą romską - przyczynili się do wykreowania obecnej do dzisiaj cygańskiej legendy flamenco (Lavaur 1996, 107-132). Gdy omawiamy historię tego fenomenu, nie możemy pominąć między innymi tak zwanych gitanas fingidas - zagranicznych tancerek, które udawały cygańskie artystki (Steingress 2006, 22). Badacze zajmujący się flamenco w jego międzynarodowym kontekście wyróżniają zazwyczaj dwa etapy kontaktów flamenco z szeroko pojętą zagranicą. Od końca XIX wieku do lat siedemdziesiątych XX wieku flamenco poza Hiszpanią było odbierane w sposób bierny - głównie poprzez przyjmowanie grup artystów z Hiszpanii. Następnie zostało oderwane od pierwotnych terenów, na których je wykonywano (hiszp. desterritorialización) (Steingress 2007, 68-70), by zyskać popularność także w innych krajach (na początku w USA, we Francji, w Japonii i Niemczech). W latach siedemdziesiątych XX wieku zaczęły powstawać pierwsze szkoły flamenco poza Hiszpanią. Następnie coraz więcej obcokrajowców zaczęło przyjeżdżać na Półwysep Iberyjski, by zapoznawać się z tą sztuką w miejscu jej powstania. Andaluzję jako kolebkę flamenco co roku odwiedza ponad 650 tysięcy turystów, którzy jako podstawowy powód swojej wizyty podają flamenco ${ }^{6} .75,1 \%$ turystów odwiedzających Andaluzję w celu skorzystania z oferty szkół flamenco ${ }^{7}$ to obcokrajowcy, na czele z Japończykami $(19,1 \%)$, Francuzami $(11,6 \%)$ i Niemcami $(9,1 \%)^{8}$.

Sewilla, stolica andaluzyjskiej wspólnoty autonomicznej, jest miejscem szczególnym na geograficznej mapie flamenco. Jest bowiem uznawana za mekkę flamenco, którą każdy jego adept powinien odwiedzić. Traktuje się ją jako źródło prawdziwego, czystego, autentycznego flamenco. Sewilla skupia największą liczbę miejsc, w których można zobaczyć i posłuchać fla-

6 Niezwykłą popularność flamenco na świecie dobrze ilustruje przykład szkoły będącej głównym miejscem prowadzonej przeze mnie obserwacji uczestniczącej - Escuela de Flamenco Ados Ángel Atienza. Od 2006 roku przewinęło się przez nią kilka tysięcy uczniów reprezentujących 107 narodowości.

7 Przy powołaniu się na niniejsze dane należy zauważyć, że zbiorcza kategoria - szkoły flamenco, obejmuje także akademie, w których można się uczyć śpiewu i gry na gitarze.

8 Wszystkie wymienione dane procentowe pochodzą z raportu La Demanda de Turismo de Flamenco en Andalucía - 2004, http://www.juntadeandalucia.es/turismocomercioydeporte/ turismoycomercio/export/sites/ctcd/archivos/estadisticas/estadisticas-oficiales-de-ctcd/484_turismo_flamenco_04.pdf. Dostęp: 18.11.2013. 
menco. Znajdują się w niej jedne z najbardziej prestiżowych szkół flamenco kształcących profesjonalistów. Szkoły flamenco w Sewilli stają się punktem wyjścia do procesu negocjowania transkulturowej tożsamości. Spotykają się w nich uczniowie z całego świata nie tylko po to, by doskonalić znajomość flamenco, lecz także budować nowe relacje społeczne na innym niż rodzimy gruncie, z osobami, z którymi łączy je jedna pasja. Akademie flamenco to także źródło ich wiedzy o kulturze flamenco: pokazach, koncertach i festiwalach. Spędzając w nich kilka godzin każdego dnia, uczniowie po części świadomie, po części nieświadomie redefiniują samych siebie w kontakcie $\mathrm{z}$ innymi. Miejsca te to przestrzeń bezpośredniego spotkania $\mathrm{z}$ autochtonami twórcami i miłośnikami kultury flamenco. To grunt, na którym dochodzi do starcia różnych światopoglądów i kultur, gdzie należy wypracować pewną nić porozumienia, by móc współpracować w tym samym celu - osiągnięciu jak najlepszych wyników w tańcu.

Należy zaznaczyć, że obecnie w profesjonalnym świecie flamenco w gronie najdoskonalszych tancerzy w Hiszpanii wciąż niewielu jest artystów obcokrajowców. Najlepsi z nich znajdują się raczej na poziomie średnim. Wciąż niewielu jest bowiem zagranicznych tancerzy w najbardziej prestiżowych kompaniach i zespołach. Ten stan rzeczy powoli się jednak zmienia9. Pod wpływem cudzoziemców ewoluuje również sewilska społeczność flamenco. Świadczą o tym inicjatywy takie jak: zajęcia z komunikacji flamenco, pokazy tańca początkujących artystów, konkursy, w których mogą brać udział cudzoziemcy, oraz sklepy z asortymentem flamenco prowadzone przez obcokrajowców. Nauczyciele zdają sobie sprawę z tego, że ich oferta musi być atrakcyjna dla zagranicznych tancerzy - dlatego uczą się języków obcych oraz wprowadzają do programów nauczania nowe zajęcia, podczas których dokonują dokładnej analizy utworów flamenco. Wszystko to, by ułatwić artystom spoza Hiszpanii naukę. Obcokrajowcy borykają się jednak z problemami związanymi z autoakceptacją oraz aprobatą innych w społeczności flamenco. Wiąże się to ze wspomnianymi już wcześniej negocjowanymi elementami tożsamości transkulturowej, związanymi z ekspresją cielesno-ruchową.

9 Najlepszym tego przykładem są postaci: Kanadyjki Chloé Brûlé-Dauphin, Amerykanki Cristiny Hall czy Japonki La Junco. Warto zauważyć, że Chloé Brûlé-Dauphin została zaproszona do występów podczas Biennale Flamenco w Sewilli - najważniejszej imprezy flamenco w Hiszpanii. W 2013 roku do składu podstawowego Andaluzyjskiego Baletu Flamenco została przyjęta pierwsza w historii cudzoziemka - Chilijka Florencia O’Ryan Zúñiga. 


\section{Ekspresja ciała - ekspresja tożsamości: taniec i ruch}

Aby zrozumieć, na czym polegają trudności w ekspresji ruchowej w kontekście flamenco, należałoby stworzyć opis tego tańca. Przy formie tak ulotnej jak ruch łatwo o sprowadzenie go do stricte technicznego opisu bądź o dużą dawkę egzaltacji. Flamenco czerpie z baletu klasycznego oraz z powiązanego z nim bolera, dlatego praca ramion i rąk w tym tańcu jest zbliżona do techniki klasycznej. Ruchy i pozycje ciała bazujące na technice klasycznej i escuela bolera są jednak zaadaptowane do flamenco (hiszp. movimientos aflamencados). W tańcu wykorzystywane są liczne obroty: piruety, chaînes oraz tak zwane złamane obroty (hiszp. vueltas quebradas) - najbardziej charakterystyczne dla tej andaluzyjskiej formy ekspresji ${ }^{10}$. We flamenco niezwykle istotny jest kontakt z ziemią - jakkolwiek tancerz wyciąga klatkę piersiową mocno ku górze, to jego stopy mocno trzymają się podłoża. Możemy zatem wyróżnić przeciwstawne kierunki: od pasa w górę - ku górze i od pasa w dół - ku ziemi. Centrum w ciele tancerza znajduje się $\mathrm{w}$ klatce piersiowej. To w dużej mierze dzięki pracy centrum taniec nabiera wyrazu. Jak już wcześniej wspomniano, bardzo długo w nauce flamenco stosowano się do zasady, że tancerze tańczą od pasa w dół, tancerki zaś od pasa w górę. Z tym podziałem łączą się dwie najbardziej charakterystyczne, jak się wydaje, cechy tańca flamenco - step oraz praca ramion i nadgarstków. Ozdobne ruchy ramion to tak zwane braceos, zaś wykończone pracą palców dłoni ruchy nadgarstków to floreos. W tańcu żeńskim obecna jest także płynna praca bioder. Druga z cech dystynktywnych flamenco to bardzo intensywny step - zapateado/taconeo. Jakkolwiek obecnie podział na flamenco „męskie” i „kobiece” częściowo ulega zatarciu, to w tradycyjnym tańcu męskim można zauważyć dużo większą powściągliwość i oszczędność ruchu, gdy chodzi o pracę korpusu. Warto pamiętać, że wbrew obiegowej opinii tancerz "tupie” tylko w stricte wyznaczonych momentach - kiedy struktura danego palo mu na to „pozwala”. Zapateado jest zatem z jednej strony pokazem technicznych umiejętności tancerza, z drugiej zaś służy mu w komunikacji z muzykami. I tak użycie określonych struktur rytmicznych stepu pozwala na zasygnalizowanie takich zmian w tańcu jak: przyspieszenie, zwolnienie, rozpoczęcie kolejnej części choreografii czy jej zakończenie. Tańcząc, w trakcie śpiewu artysta wykonuje tak zwane marcaje - kroki taneczne

10 Vueltas quebradas to obroty, których cechą charakterystyczną jest wyjście z pionu - „złamanie” tułowia wpół, przy czym punktem odniesienia dla wzroku tancerza, w trakcie obrotu, jest podłoga (dół) i sufit (góra), nie zaś przód i tył. 
oraz zsynchronizowane z nimi ruchy rąk i nadgarstków, które podkreślają śpiew oraz rytm danego utworu, a także je interpretują. Należy pamiętać, że charakter ruchu w tańcu jest we flamenco determinowany przez wybór określonej formy tańca (palo flamenco). Inaczej zatem będzie wyglądał ruch $\mathrm{w}$ formach poważnych czy wręcz tragicznych w swojej wymowie, inaczej natomiast w stylach radosnych czy tych opierających się na elegancji i gracji bądź w tych wywodzących się z tradycji ludowej. Niezależnie od omówionych wcześniej cech dystynktywnych tańca flamenco należy pamiętać, że zwłaszcza w kontekście flamenco wykonywanego „prywatnie” społeczność flamenco najbardziej ceni sobie rozumienie struktury muzycznej utworu i jego odpowiednią interpretację. Czysta technika zdaje się w tym kontekście elementem drugoplanowym.

Podczas charakterystyki tańca flamenco należy również omówić kwestię stroju wykonawców. Stereotypowa tancerka flamenco przypomina Mériméerowską Carmen. Najbardziej typowe kobiece stroje do tańca to długie, bogate w falbany suknie zdobione w grochy lub kwiaty. Kwiaty są także elementem wpinanym we włosy (najczęściej mamy tu do czynienia ze sztucznymi różami upinanymi na środku bądź z boku głowy - w zależności od panującej w danym momencie mody). Poza kwiatami we włosy wpina się tak zwane peinetas - małe ozdobne grzebyki, do uszu zaś wkłada okazałe kolczyki. Do najbardziej popularnych rekwizytów tanecznych należą: wachlarze (abanicos), chusty (mantónes de Manila), laski (bastónes), kastaniety (castañuelas/palillos), kapelusze (sombreros) oraz suknie/spódnice z długim trenem (bata de cola). Strój męski to najczęściej eleganckie spodnie, krótka kamizelka i koszula (przyozdobione wzorzystą apaszką) bądź po prostu wygodny garnitur. Zarówno mężczyźni, jak i kobiety do tańca używają charakterystycznych butów na obcasie, podbitych na palcach i pięcie gwoździami, które wzmacniają dźwięk podczas stepu. Są one zrobione ze skóry bądź z zamszu. Z flamenco kojarzone są też określone kolory: czerń i czerwień. Oczywiście w praktyce tancerki i tancerze korzystają z niezliczonych wzorów i kolorów strojów do tańca, jednak w granicach pewnej bardzo określonej estetyki. Na silne odstępstwa od wymienionych wcześniej wizualnych zasad decydują się raczej artyści już uznani, słynni z eksperymentowania. Obcokrajowcy także zaczynają zrywać z typowymi dla flamenco przedstawieniami wizualnymi ${ }^{11}$.

${ }^{11}$ Doskonałym tego przykładem jest wspominany przez jedną z respondentek spektakl No frills. 


\section{Ekspresyjność}

Zdaniem kulturoznawcy Wojciecha Klimczyka taniec jako forma budowania wspólnoty jest narzędziem światopoglądowego sporu. Jeśli przyjąć za badaczem, że „poruszając się w taki, a nie inny sposób, jednostki i społeczności budują konkretną kinetyczną tożsamość” (Klimczyk 2015, 19), a także „dokonują politycznego wyboru określonych wartości” (Klimczyk 2015, 19), w analizowanym tutaj kontekście należałoby uznać tożsamość kinetyczną za jeden z elementów tożsamości transkulturowej. Już na najbardziej podstawowym poziomie analizy można stwierdzić, że obcokrajowcy wybierający flamenco jako formę ekspresji doskonale wpisują się w tę tezę. Decydując się na związanie życia zawodowego z flamenco w Sewilli, wchodzą w stosunek władzy $\mathrm{z}$ autochtonami, stając się grupą podporządkowaną. Z tym zagadnieniem wiąże się analiza relacji flamenco i władzy przeprowadzona przez socjologa Francisca Aix Gracię (Aix Gracia 2014, 430). Nazwani przez niego „artystami uświęconymi” uznani artyści - autochtoni, znajdują się według badacza na pozycji dominującej w polu flamenco. Dzięki temu nieskrępowanie korzystają z dostępu do wyróżnionych przez Jeana Bourdieau kapitałów: ekonomicznego, społecznego i symbolicznego (Bourdieu, 1986). Dla Gracii szczególnie istotny jest ten ostatni. Dzięki niemu uprzywilejowani - uznani - artyści decydują o tym, co we flamenco ma wartość, a co jest jej pozbawione. Innymi słowy mogą stwierdzać, czym flamenco jest i czym nie jest. W tym kontekście socjolog wybiera do analizy bardzo interesujący z punktu widzenia tej pracy element kapitału symbolicznego, a mianowicie - ekspresję (hiszp. la expresividad). Definiuje ją jako: umiejętność posługiwania się muzyką lub tańcem w taki sposób, by z łatwością wywoływały one u widza odczucia i uczucia, które dany artysta chce przekazać (Aix Gracia 2014, 430). Jak stwierdza badacz, a trudno się z nim nie zgodzić, to właśnie dzięki odpowiedniej ekspresji flamenco zyskało wiele ze swej popularności, zaś artyści dominujący na scenach Hiszpanii i świata odnieśli sukces. To z ekspresją można łączyć kategorie takie jak: czystość (hiszp. pureza), „prawdziwość/autentyczność czy duende (swego rodzaju siłę, ducha, „duszę” flamenco).

Aix Gracia zauważa, że początkujący artyści flamenco (hiszp. aspirantes) są zmuszeni do odłożenia „na później” pracy nad swoją ekspresyjnością, gdyż przez bardzo długi czas tkwią w fazie, w której muszą perfekcyjnie opanować technikę oraz zapoznać się z dziedzictwem kulturowym flamenco. Jest to moim zdaniem wymierzona w nich swego rodzaju przemoc symboliczna. Rozwijają się bowiem jako artyści w przekonaniu, że bez doskonałej znajo- 
mości kultury flamenco: jego alfabetu, kodów (związanych z poszczególnymi formami śpiewu i tańca) oraz techniki nie są „godni”, by występować i przekazywać emocje. Sam Aix Gracia podaje przykłady wypowiedzi na temat artystów pretendujących do bycia elitą flamenco, które jak mówi - miażdżą ich aspiracje. Przywoływana przez socjologa krytyka dotyczy niewystarczająco dobrego czy profesjonalnego wykonawstwa. Młodzi stażem adepci flamenco mogą tańczyć z gracją, jednak nic poza tym (Aix Gracia 2014, 431). W związku z tym proces ich nauki wydłuża się w nieskończoność. Nigdy bowiem nie są wystarczająco dobrzy technicznie i nigdy nie posiadają wystarczającej wiedzy na temat struktur poszczególnych palos, by móc skupić się na ekspresji. Nie odnosi się to jednak do artystów drugiej generacji flamenco, którzy dzięki temu, że wychowywali się w otoczeniu flamenco, wcześnie zrozumieli, czym ono jest. Uważam, że sytuacja obcokrajowców znajdujących się w przestrzeni flamenco bądź - jak to określa Aix Gracia za Bourdieu (1995, 344-345) - w polu flamenco jest analogiczna, a nawet dużo bardziej złożona. Na początku profesjonalnej drogi nie dysponują oni ani kapitałem społecznym, ani kulturowym, ani symbolicznym. Zaczynają je dopiero mozolnie budować. Jedynie kapitał ekonomiczny jest tym, który zazwyczaj posiadają, niemniej w większości przypadków im bardziej wydłuża się ich pobyt w Sewilli, tym bardziej te zasoby maleją.

Taniec to przede wszystkim ruch $^{12}$. W ruchu zaś to ciało odgrywa szczególną, podwójną rolę w symbolicznej walce obcokrajowców o legitymizację ich obecności w społeczności flamenco. Z jednej strony jest ono bowiem przestrzenią kreacji i ekspresji siebie (Dziuban 2013, 84), z drugiej zaś to kluczowy czynnik wpływający na podporządkowanie obcokrajowców grupie dominującej (Andaluzyjczykom, Cyganom czy w szerszym kontekście - Hiszpanom). Z tego punktu widzenia najważniejszymi elementami cielesności dla zagranicznych adeptów flamenco byłyby: ekspresja ruchowa, wygląd ciała oraz (choć w mniejszym stopniu) strój.

\section{Ekspresja ruchowa}

Taniec flamenco łączy się z charakterystyczną konwencją ruchową, w której tworzeniu bardzo ważną rolę odgrywa tradycja. Na początku nauki należy tańczyć tak, jak ona nakazuje. Dopiero w późniejszym czasie tancerze mogą rozpocząć poszukiwania własnej formy ekspresji będącej częścią składową

${ }^{12}$ Choć oczywiście także bezruch. 
ich powoli budowanego kapitału symbolicznego. Zdarza się jednak, że artyści z grupy dominującej blokują rozwój ekspresji u początkujących adeptów flamenco. Zagadnienie to dobrze ilustruje poniższa wypowiedź tancerki z Czech, opowiadającej o rozmowie, jaką przeprowadziła z nią nauczycielka - Hiszpanka:

Powiedziała mi: „Na przykład ty potrafisz tańczyć bardzo podniośle, bo jesteś stamtąd - z kraju zimna i wielkiej ciemności. Masz bardzo dobry compás - bo wy macie bardzo matematyczne podejście, ale nigdy nie będziesz tańczyła z uczuciami, bo w twoim kraju jest bardzo zimno i w twoim sercu w związku z tym również". $\left[\mathrm{T}_{1}\right]^{13}$

Po tej rozmowie moja respondentka długo czuła się „zablokowana” tanecznie. Uwierzyła nauczycielce, że pewne formy flamenco (o bardzo charakterystycznej ekspresji) nigdy nie będą dla niej dostępne ${ }^{14}$. Dopiero po pewnym czasie zaczęła się „buntować” przeciw takiemu jej postrzeganiu. We flamenco trudno jest jednak całkowicie odejść od narzuconej kulturowo konwencji tańca. Dlatego też słuszne wydaje się stwierdzenie, że tancerze, obierając tę właśnie sztukę jako swój zawód i pasję, dokonują wyboru bardzo określonej tożsamości kinetycznej. Tak też się dzieje z cudzoziemcami, którzy zdecydowali się na flamenco jako formę realizacji swojego tożsamościowego projektu. Obcokrajowcom trudno jest jednak zaakceptować pewne jej elementy, o czym najlepiej świadczy przytaczana wypowiedź polskiej tancerki:

Z jednej strony to jest już tylko sztuka, która ma coś wyrażać, ale to jest cały ten skansen. My się musimy ubrać w te falbanki, musimy tańczyć por bulerías, por alegrías na styl tablao. Raz por alegrías - jestem zadziorną Cyganką, raz guajira - to jestem uwodzicielska, por bulerías, to jestem Cyganichą z grubą dupą. Nie potrafię tego kupić. [...]. Zastanawiam się, po co tańczę, czego chcę od tańca, co mi to daje, co chcę osiągnąć, i to jest dla mnie ta trudność. Nie wiem, jak to ugryźć, bo tańcząc taniec nowoczesny, nie masz tych problemów, bo to jest uniwersalne. Masz taniec nowoczesny rosyjski, polski, amerykański, ale oni się spotykają i we trójkę zatańczą. A to jest tak silnie naznaczone jakimś terytorializmem i konkretną kulturą. Muszą być trochę luzaccy, trochę zadziorni, trochę

${ }^{13}$ W tekście kolejne rozmówczynie oznaczone są symbolami: T (tancerka) 1, 2, 3.. W tekście zaznaczam pochodzenie respondentek, ponieważ wydaje mi się to bardzo istotne w kontekście poruszanego przeze mnie tematu.

${ }^{14}$ Warto w tym miejscu jednak zaznaczyć, że zarówno w tańcu, jak i w muzyce artyści nie wykonują wszystkich możliwych form flamenco, a jedynie te, w których „czują się” najlepiej. Pewne palos nie korespondują bowiem z ich stylem tańca/śpiewu/gry czy po prostu z gustem. 
głośni, a ja jestem dużo cichsza i delikatniejsza niż Hiszpanki. Zastanawiam się, czemu ja muszę tańczyć tak jak Hiszpanki, łapiąc się za dupę w buleríi, skoro ja nie jestem taka jak one. Z kolei mówią ci, że nie, bo por bulerías tańczy się tak, musisz być taka. Ale kto mówi, że muszę być taka jak one? Stąd mam takie kłopoty z ekspresją. [T2]

Wspominana przez respondentkę forma tańca - bulerías, jest zapewne tą, która powoduje u niedoświadczonych tancerzy i tancerek największy stres. Okazuje się bowiem, że paradoksalnie tym, co paraliżuje młodych adeptów flamenco jest element, który powinien sprawiać im najwięcej przyjemności - tak zwany fin de fiesta - stały element pokazów flamenco. To moment, w którym występ oficjalny się kończy, artyści zaś zapraszają na scenę wszystkich, którzy mają ochotę zatańczyć bulerías ${ }^{15}$ - palo przez wielu uważane za najtrudniejsze w całej gamie tańców flamenco. Bulerías to forma stricte zabawowa, o prześmiewczym, radosnym charakterze, w której tancerz pokazuje, jak potrafi żartować $\mathrm{w}$ tańcu, bawiąc się nim ${ }^{16}$. Wymaga to pełnego rozluźnienia, a zarazem rozległej znajomości wersów i struktury typowych bulerías, których jest bardzo wiele, a ich uczenie się jest niezwykle czasochłonne. $\mathrm{Z}$ założenia w bulerías nie liczy się poziom techniczny tancerza (choć zazwyczaj wszyscy chcą się pochwalić skomplikowanymi stepami w swoich występach). To, co naprawdę jest istotne, to czucie i rozumienie muzyki. Aby poznać strukturę bulerías, należy poświęcić bardzo dużo czasu na osłuchanie się z tą formą. To właśnie podczas fin de fiesta tancerze obcokrajowcy zostają poddani najostrzejszej krytyce. Zabawa utworem jest w tych warunkach nie lada wyzwaniem dla początkujących artystów. Tancerz „odnajdujący się” w bulerías zostaje zaakceptowany przez obecne podczas jego występu gremium. Umiejętność tańczenia bulerías jest identyfikowana z „byciem-w-kulturze flamenco”. Dlatego wielu początkujących tancerzy cierpi na paniczny wręcz lęk przed wyjściem na scenę, by wykonać ten taniec. Obecnie organizowane są kursy poświęcone jedynie bulerías, podczas których - zazwyczaj przez godzinę dziennie - tancerze przy udziale śpiewaka i gitarzysty uczą się na prostych (bądź bardziej skomplikowanych) krokach, jak

${ }^{15}$ Niemniej należy podkreślić, że w praktyce podczas występów w tablaos skierowanych do turystów lub gdy na scenie znajdują się "gwiazdy" flamenco, nie ma zwyczaju zapraszania do tańca osób z widowni. Niepisaną zasadą jest również, że gdy na widowni są uznani profesjonaliści, to im oddaje się scenę na fin de fiesta. Bardzo źle jest widziane, jeśli w takim momencie ktoś niedoświadczony pojawia się na scenie. Zostaje on poddany symbolicznemu ostracyzmowi.

${ }^{16}$ Zdarza się, że podczas fin de fiesta wykonuje się także inną formę flamenco - tak zwane tangos. Jest to jednak stosunkowo rzadka praktyka. 
poprawnie tańczyć tę formę. Jest to tym trudniejsze, że przy niemal każdym typie bulerías istnieje kilka możliwych scenariuszy, według których tancerz może postępować. Podczas fin de fiesta tancerze i muzycy stają w półkolu na scenie (gdy obecna jest widownia) bądź po prostu w kole. Zabawę rozpoczynają gitarzyści i śpiewacy, zaś wszyscy inni wyklaskują rytm (hiszp. palmas). Dalej w odpowiednim momencie do środka koła wchodzą kolejni tancerze, prezentując krótkie pataitas por bulería - miniimprowizacje do muzyki. Tancerz wykonujący bulerías musi wiedzieć, kiedy rozpocząć oraz w którym momencie skończyć taniec (nie wypadając przy tym z rytmu), co w praktyce jest bardzo trudne z powodu niezwykle szybkiego tempa. Fin de fiesta dobrze obrazuje ujawnianie się granicy między „swoimi” a „obcymi” w społeczności flamenco. Jest to też moment, w którym zagraniczni artyści mogą dokonać aktu transgresji, przekraczając tę symboliczną granicę. I tak obcokrajowcy dzielą się na tych, którzy niemal zawsze wychodzą na scenę, by spróbować swoich sił i „przemóc się”, oraz na tych, którzy ze względu na stres nie są w stanie tego dokonać całymi latami. Warto zauważyć, że znajomość zasad improwizacji por bulerías pozwala na ogromny krok naprzód $\mathrm{w}$ inicjacji flamenco.

\section{Ciało}

Na pewnym etapie nauki cudzoziemcy zaczynają dekonstruować wizualną część mitu flamenco. Dlatego autorka poniższej wypowiedzi postanowiła stworzyć, wraz ze swoimi dwiema krajankami, przedstawienie odzierające flamenco $\mathrm{z}$ typowej dla niego estetyki $\mathrm{i}^{17}$. Na pytanie o charakter owego tanecznego projektu odpowiada:

Cały czas się jeszcze formułuje. Myślę, że pierwsze przedstawienie, które nazywa się No frills [„Bez falban” - przyp. J.R.], było i jest taką próbą i za każdym razem kiedy je gramy, ewoluuje, staje się lepsze i rośnie. Chodziło o odrzucenie ozdób, pamiętaj, że Y jest nie tylko Angielką, jest też czarna. Więc jej fizjonomia... ona czuje się trochę śmieszna, przypinając sobie na przykład kwiat. Dlaczego? Po co ma się ubierać jak Cyganka flamenco? Będąc tak piękną, jaka jest... to trochę to, o co nam chodzi: przestaniemy przebierać się za Andaluzyjki z tablao. Odrzucimy groszki i falbany, zobaczymy, co się stanie, i będziemy szukać naszej kwintesencji, szukając naszej szczerości i uczciwości Angielek. No więc to poszukiwanie się zaczęło. Poszukiwanie odpowiedzi na pytanie: co takiego

${ }_{17}$ Oficjalna strona spektaklu: https://www.dotdotdotdance.com/no-frills. Dostęp: 4.03.2021. 
mają tutejsi flamencos? Co to jest? Jakie jest? Z jakiegoś powodu narodziło się tutaj, ta radość, jego istota. [T3]

Temat ten staje się tym bardziej żywy, bo to właśnie aspekt fizyczny staje obcokrajowcom na przeszkodzie w znalezieniu miejsca na hiszpańskich scenach flamenco. Im mniej tancerka czy tancerz podobni są do „wzorca z Sèvres" flamenco - ciemnowłosej postaci o śniadej karnacji, tym mają więcej trudności w znalezieniu pracy na rynku flamenco. W tym też kontekście mówi się o dyskryminacji czy nawet rasizmie. Moi respondenci nie chcieli rozmawiać na ten temat przy włączonym mikrofonie, dlatego wiele odnoszących się do niego historii usłyszałam nieoficjalnie. Najbardziej kontrowersyjna z nich dotyczyła pewnego tablao, kiedy to po występie czarnej tancerki odbyło się zebranie, podczas którego zaczęto podawać w wątpliwość możliwość jej występów w tym miejscu ze względu na kolor skóry. Argumentacja przeciw opierała się na założeniu, że turyści przyjeżdżający do Sewilli pragną oglądać flamenco w wykonaniu „typowych” Hiszpanów. Przy tej okazji należy zauważyć, że takie myślenie jest faktycznie bardzo popularne wśród zagranicznych wycieczkowiczów ${ }^{18}$. Według ich stereotypowego wyobrażenia tancerka flamenco to właśnie śniada (ale nie czarna), najczęściej ciemnowłosa dziewczyna. Czarna tancerka nie pasuje więc do tej wizji. Może to prowadzić do zwodniczej konstatacji, że tancerki bądź tancerze, nawet andaluzyjskiego pochodzenia, ale o odmiennym kolorze skóry, nie powinni zajmować się flamenco, ponieważ kłóci się to ze stereotypową wizją tej sztuki.

Problem odmienności fizycznej przewija się bardzo często w wywiadach z Azjatkami, zwłaszcza z Japonkami, które - jak już wspomniano wcześniej szczególnie upodobały sobie flamenco jako formę ekspresji. Dobrze obrazuje to poniższy cytat:

Popatrz: choć mówi się o obcokrajowcach [w kontekście dyskryminacji - przyp. J.R.], ja myślę, że wśród obcokrajowców są też tak jakby grupy. Na przykład: ja jestem Japonką, więc po części mam orientalny wygląd fizyczny, a inni obcokrajowcy nie posiadają rysów orientalnych. No więc być może Francuzce, Angielce czy Amerykance, która wygląda na Hiszpankę czy Cygankę, będzie łatwiej znaleźć pracę, na przykład w tablao. [T4]

${ }^{18}$ Paradoksalnie zatem to obcokrajowcy wyświadczają niedźwiedzią przysługę zagranicznym artystom flamenco w Hiszpanii. 
Zagadnienie to jest tym bardziej skomplikowane, że niejednokrotnie to sami obcokrajowcy (tu Japończycy) narzucają sobie konieczność bycia jak Andaluzyjczycy, poniekąd wstydząc się własnej fizjonomii. Jedna z japońskich respondentek, której córka jest profesjonalną tancerką flamenco w Sewilli, przyznaje:

[...] moja córka nie wygląda na Japonkę, jest pół Japonką, pół Hiszpanką, więc to co innego, jest trochę inna niż Hiszpanki, ale jeśli się pomaluje, można to ukryć. Bo niektóre Cyganki mają orientalne rysy twarzy, jak by to powiedzieć z Egiptu ${ }^{19} \cdot\left[\mathrm{T}_{4}\right]$

Głęboką sprzeczność w samopostrzeganiu obcokrajowców we flamenco bardzo dobrze obrazuje poniższa zaskakująca wypowiedź tej samej Japonki mieszkającej przeszło dwadzieścia lat w Sewilli:

Ja wszystkim to powtarzam: tutejszy świat flamenco jest bardzo zamknięty dla obcokrajowców. Zwłaszcza na orientalne twarze. Być może jeśli Europejki się do tego nie przyznają, ludzie myślą, że są Hiszpankami, więc mogą tańczyć $\mathrm{w}$ każdym miejscu. Ale my z twarzami orientalnymi nie możemy oszukiwać, z naszymi twarzami, wiesz? Wiele kompanii tanecznych nie chce obcokrajowców, wiele tablaos nie chce cudzoziemek. Bo interes tablao jest dla guiris ${ }^{20}$. Ja rozumiem, że guiris chcą widzieć tańczących ludzi stąd.

J.R.: Więc myślisz, że istnieje ta „dyskryminacja”?

Nie dyskryminacja, to jest logiczne, naprawdę ja tak myślę... Amerykanin ubrany w kimono... nie pasuje. Tak czy nie? Tak samo: japońska twarz, ciało Japonki, Azjatki, prawda? Sukienka flamenco, ha ha ha, nie pasuje. To trzeba zrozumieć. Więc jeśli chce żyć z flamenco, musi wrócić do swojego kraju. [T4]

Zazwyczaj jednak obcokrajowcy buntują się przeciw takiemu stanowi rzeczy i mimo przeciwności starają się podążać obraną przez siebie ścieżką. Kolejny fragment wypowiedzi respondentki z USA dobrze nakreśla tę sytuację:

Na przykład startujesz w konkursie i tańczysz dobrze, ale nie wygrywasz, bo jesteś z zewnątrz. Albo komentarze rzucane przez ludzi, którzy cię widzą, na

${ }^{19} \mathrm{~W}$ wypowiedzi tej przewija się także wątek pokutującej w środowisku flamenco legendy, według której andaluzyjscy Cyganie wywodzą się z Egiptu - stąd uwaga dotycząca „orientalnych”, egipskich rysów twarzy.

${ }^{20}$ Przypomnijmy - termin guiri znaczy tyle co zagraniczny turysta. Często jednak, zwłaszcza w Andaluzji, jest on nacechowany negatywnie i ironicznie. 
przykład: „Zmień imię, dzięki temu będziesz miała więcej pracy” albo: „Zafarbuj włosy, bo jesteś blondynką". Wiesz, to są rzeczy, których nie rozumiem, bo sztuka to forma ekspresji. Więc nie można zwracać uwagi na aspekt fizyczny. To jest wchodzenie w środek kwestii tożsamościowych.

Jedziesz na festiwale, a tam prawie nigdy nie ma obcokrajowców, przynajmniej jako tańczących artystów. Myślę, że w tym kontekście polityka jest bardzo skorumpowana. Nigdy nie wspomaga artystów, a już zupełnie nie cudzoziemców. To szkoda, bo tak naprawdę obecnie flamenco jest żywe dzięki ludziom, którzy przyjeżdżają z zagranicy, żeby się uczyć. Dajemy im dużo pieniędzy... mnóstwo! Rok temu pewna telewizja spytała mnie dokładnie o to... zrobili jakieś statystyki dotyczące tego, ile pieniędzy obcokrajowcy tu zostawiają. I podawali liczby... sto tysięcy euro rocznie! Tylko rocznie, to mnóstwo pieniędzy! To dzięki zainteresowaniu obcokrajowców artyści stąd wyjeżdżają za granicę, żeby występować i uczyć, i zarabiają więcej pieniędzy niż tu.

J.R.: A jakie masz doświadczenia w pracy poza Hiszpanią?

Generalnie dobre, ale zdarzyło mi się kilka sytuacji, w których pewne osoby nie chciały lekcji ze mną albo nie chciały zaprosić mnie do prowadzenia kursu, mówiąc: „Nie mogę cię wziąć do poprowadzenia warsztatu, bo jesteś z zagranicy, nie będziesz uczyć w mojej szkole, bo jesteś cudzoziemką". No dobra, ale uczniowie też są z zagranicy, to bardzo duża sprzeczność. Niektórzy uczniowie nie chcą zapisać się na kurs, który prowadzi ktoś spoza Hiszpanii. No trudno, akceptuję to i podążam własną ścieżką. [T5]

\section{Podsumowanie}

Jak pokazała wcześniejsza analiza, ciało w kulturze flamenco odgrywa istotną, podwójną rolę - jest czynnikiem autodefiniującym oraz elementem wykluczenia lub „dyskryminacji” ze strony autochtonów i zagranicznych widzów, którzy utożsamiają tancerkę/tancerza flamenco z określonym „typem fizycznym”. Niektórzy zatem pragną upodobnić się do autochtonów, inni zaś od nich odróżnić. Jak słusznie zauważa Agata Dziuban za Anthonym Giddensem: „ciało późnonowoczesne jest niedomknięte” (Dziuban 2013, 79) czy też „niedokończone”, podlega w związku z tym różnego rodzaju przekształceniom w procesie realizacji tożsamościowego projektu jednostki, zgodnie z jej zmiennym obrazem siebie (Dziuban 2013, 79). Ciało tancerzy flamenco także jest „niedomknięte” - otwarte na transkulturową wymianę. W wymianie tej niektórzy zagraniczni tancerze niejednokrotnie ulegają dominującym wzorcom, inni - nie będąc w stanie w pełni zaakceptować narzucanej im 
wizji cielesności i ruchu we flamenco - odczuwają ciągłą potrzebę negocjowania tych wzorców z otoczeniem. Przywołane przeze mnie przykłady pokazują, że uniwersalność flamenco, postulowana przez wspomnianego na początku tekstu Esteveza, wydaje się przynajmniej częściowo złudna. Może też realizować się jedynie w pewnych wymiarach i dzięki temu nie narusza funkcjonującego w społeczności flamenco status quo. Owo status quo opiera się na relacjach władzy i podporządkowania. Obcokrajowcy wkraczający w społeczną przestrzeń flamenco w Sewilli wydają się je jednak częściowo burzyć. Ich determinacja, by przyjąć określoną tożsamość kinetyczną, powoduje, że zdobywają coraz szerszą znajomość kodów, którymi operuje flamenco. Niełatwe transkulturowe negocjacje na płaszczyźnie ekspresyjności, ekspresji ruchowej i cielesności powodują, że zagraniczni adepci flamenco krok po kroku zbijają symboliczny kapitał, który przynajmniej niektórym z nich pozwoli zaistnieć na hiszpańskich i międzynarodowych scenach.

\section{Bibliografia}

Aix Gracia, Francisco. 2014. Flamenco y poder. Un estudio desde la sociología del arte. Madrid: Fundación SGAE.

Bourdieu, Pierre. 1986. „The Forms of Capital”. W Handbook of Theory and Research for the Sociology of Education, edited by John G. Richardson. New York: Greenwood Press.

Bourdieu, Pierre. 1995. Las reglas del Arte. Génesis y estructura del campo literario. Barcelona: Anagrama.

Cruces-Roldán, Cristina. 2002. Más allá de la música. Antropología y Flamenco (I). Sociabilidad, Transmisión y Patrimonio. Sevilla: Signatura Ediciones.

Dziuban, Agata. 2013. Gry z tożsamością. Tatuowanie ciała w indywidualizującym się społeczeństwie polskim. Toruń: Fundacja na Rzecz Nauki Polskiej.

Dowgiało, Emilia. 2018. O flamenco polskim piórem... Kulturowe realia i słowne bariery. Wrocław: Wydawnictwo Wyższej Szkoły Filologicznej.

Iglesias Jiménez, Eduardo. 2019. Flamenco por derecho Producción social de bordes y fronteras, praca doktorska. Dostęp: 4.03.2021. https://eprints.ucm.es/id/eprint/50862/1/ T40796.pdf.

Klimczyk, Wojciech. 2015. Wirus mobilizacji. Taniec a kształtowanie się nowoczesności (1455-1795), t. 1. Kraków: Universitas.

Kubiaczyk, Filip. 2013. Nowoczesność kolonialność i tożsamość: perspektywa latynoamerykańska. Poznań: Wydawnictwo Naukowe UAM.

La Demanda de Turismo de Flamenco en Andalucía - 2004. Dostęp: 18.11.2013. http://www. juntadeandalucia.es/turismocomercioydeporte/turismoycomercio/export/sites/ctcd/ archivos/estadisticas/estadisticas-oficiales-de-ctcd/484_turismo_flamenco_04.pdf.

Lavaur, Luis. 1996. Teoría Romántica del Cante Flamenco. Sevilla: Signatura Ediciones.

Lorente Rivas, Manuel. 2005. „El flamenco como transculturación”. Música oral del sur 6.

Lorente Rivas, Manuel. Transculturaciones flamencas. Varia inflexiva, 2004. Dostęp: 20.05.2012. http://www.sibetrans.com/trans/a197/transculturaciones-flamencas-varia-inflexiva. 
Ortiz, Fernando. 2002. Contrapunteo cubano del tabaco y el azúcar. Madrid: Catedra.

Romanowska, Jadwiga. 2019. „Kształtowanie się relacji widz - artysta we flamenco na przykładzie praktyki fin de fiesta”. Magazyn Antropologiczno-Społeczno-Kulturowy „Maska” 43, nr 3: 33-44.

Schreiner, Claus, ed. 1999. Flamenco. Gypsy Dance and Music from Andalusia. Portland: Amadeus Press.

Steingress, Gerhard. 2005. Sociología del Cante Flamenco. Sevilla: Signatura Ediciones.

Steingress, Gerhard. 2006. ...Y Carmen se fue a París. Un estudio sobre la construcción artística del género flamenco (1833-1865). Córdoba: Almuzara.

Steingress, Gerhard. 2007. Flamenco Postmoderno: Entre tradición y heterodoxia. Un diagnóstico sociomusicológico (Escritos 1989-2006). Sevilla: Signatura Ediciones.

Welsch, Wolfgang. 1998. Transkulturowość. Nowa koncepcja kultury. Tłum. Berenika Susła, Jacek Wietecki. W Filozoficzne konteksty rozumu transwersalnego. Wokół koncepcji Wolfganga Welscha, red. Roman Kubicki. Poznań: Fundacja Humaniora.

Welsch, Wolfgang. 1999. „Transculturality: The Puzzling Form of Cultures Today”. W Spaces of Culture: City, Nation, World, edited by Mike Featherstone, and Scott Lash. London: Sage.

Welsch, Wolfgang. 2004. „Tożsamość w epoce globalizacji. Perspektywa transkulturowa”. Tłum. Krystyna Wilkoszewska. W Estetyka transkulturowa, red. Krystyna Wilkoszewska. Kraków: Universitas. 


\title{
Foreigners in Flamenco Culture: the Problem of Identity Negotiation
}

\begin{abstract}
The research problem presented in this text is the negotiation of transcultural identity as exemplified by foreigners enrolled in flamenco dance schools in Seville who are or aspire to be professional flamenco dancers and compete on the Spanish labour market in the flamenco industry. Foreigners are a definite majority at Seville's dance schools, whose existence depends on them. By deciding to spend a prolonged period of time in Seville, they enter a field of transcultural exchange and become involved in power relations of subordination and domination. Being a subordinate group, foreigners need to negotiate their place in the flamenco community on an ongoing basis. Their situation and relations developing in Seville are well-described through the categories of transculturation/transculturality and transcultural identity. Foreigners wishing to engage in the professional world of flamenco in Seville or, more broadly, in Spain, construct their identity by negotiating its individual elements. Three of them are discussed in the text: expression, movement and body. They are self-defining factors and elements that determine the exclusion and/or "discrimination" of indigenous people and foreign viewers.
\end{abstract}

KEYWORDs: dance, flamenco, identity, transculturation

JADwiga RomanowsKa - PhD in cultural studies, certified dance instructor. Her research interests focus on the concept of transculturalism and transcultural identity, postcolonial studies as well as broadly understood anthropology of dance. 